\title{
Prehistoric and Medieval Skis from Glaciers and Ice Patches in Norway
}

\author{
Espen Finstad ${ }^{1}$, Julian Martinsen ${ }^{2}$, Runar Hole $^{3}$ and Lars Pilø ${ }^{1}$ \\ 1. Oppland County Council; 2. Museum of Cultural History, \\ University of Oslo; 3. Tarandus AS.
}

Lars.Holger.Pilo@oppland.org

Traditionally, ski history has relied on preserved skis from bogs, on rock carvings depicting skiers and on written sources. The on-going melting of mountain ice has led to the discovery of ancient skis from a new context. In this paper, we present ski finds from glacial ice in Norway, dated from the first millennium BCE to the Medieval Period. The finds of skis from glacial ice shed new light on the ski history of NorthWestern Europe-the development, the context of use in a high-alpine landscape and the skiing technique. One of the finds provides the earliest date yet for the use of fur on the underside of skis.

\section{Introduction}

The melting of mountain ice due to climate change has led to the development of a new archaeological discipline-glacial archaeology (Andrews and MacKay 2014; Dixon et al. 2014; Reckin 2013). Oppland County Council and the Museum of Cultural History, University of Oslo have cooperated in this field since 2006, with a permanent Glacier Archaeology Program ongoing in Oppland County since 2011. Well over 2000 artefacts have been recovered, making Oppland the most finds-rich region in glacial archaeology worldwide. The high number of artefacts from the ice in the county is probably in part caused by the short distance between the densely settled valleys and the high mountain ice.

In this paper, we present interesting new ski-historical evidence from the glacial ice in Oppland. Recently, the Lendbreen and Digervarden ice patches have released

Keywords: ski history, climate change, ice patch, mountain transport, Norway, Iron Age

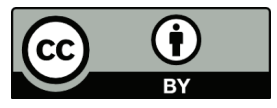




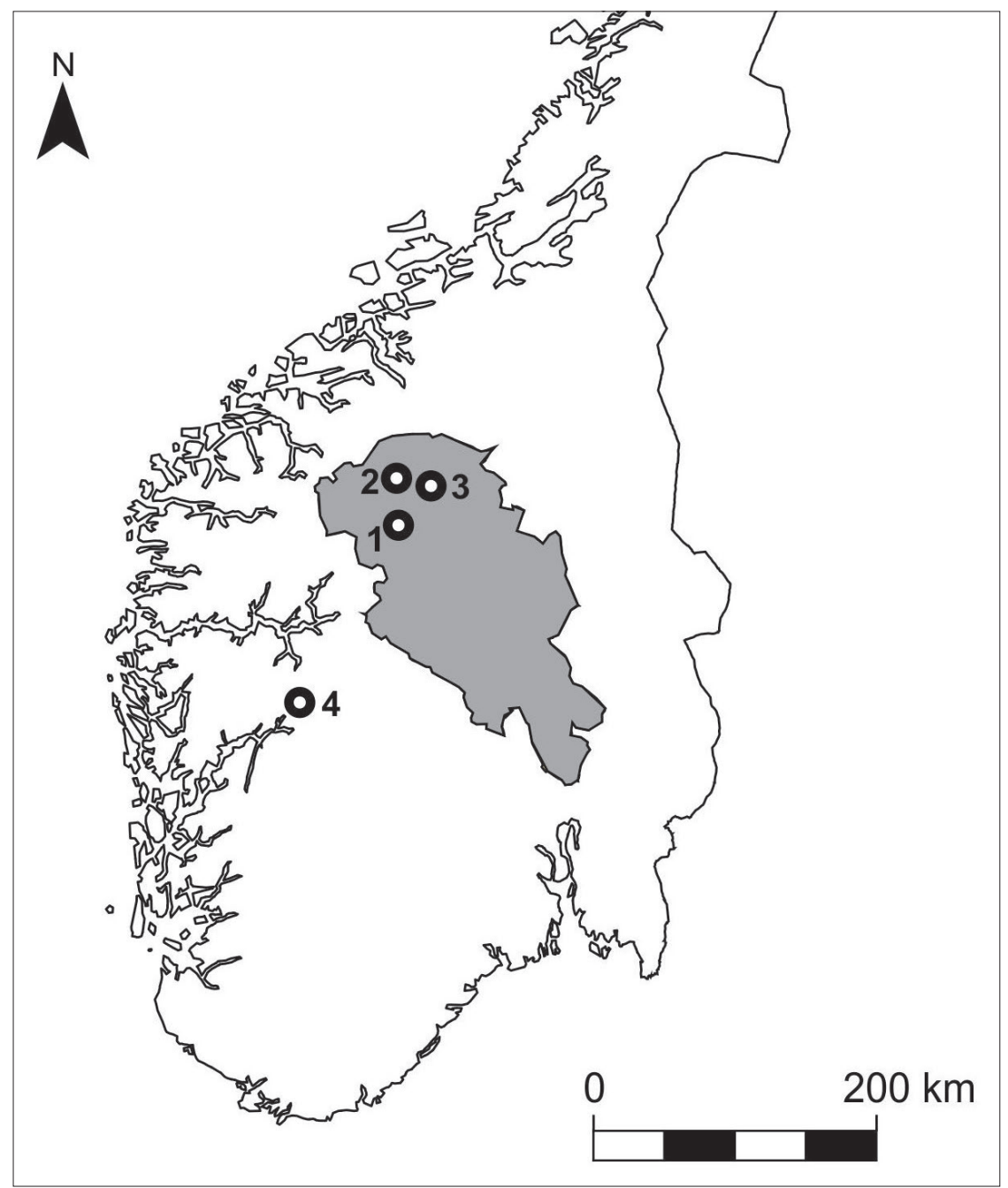

Figure 1 Map of Southern Norway with Oppland County marked in grey. Find spots for main ski finds from glacial ice. 1. Lendbreen; 2. Digervarden; 3. Dalfonn; 4. Vossa-Skavlen. Drawing: Lars Pilø, Oppland County Council.

two prehistoric skis. Both were found and recovered by the Glacier Archaeology Program. Previously, there were four known finds of skis from the ice in Norway. The earliest find is from Vossaskavlen in Hordaland County, and was recovered as early as 1931. Another, very similar ski was recovered here in 1963. Later, two skis were found at Dalfonn in Oppland County, in 1980 and 2002 respectively.

Traditionally, ski history has relied on preserved skis from bogs, on rock carvings depicting skiers and on written sources. The finds of skis from glacial ice shed new light on the ski history of North-Western Europe-the development, the context of use in a high-alpine landscape and the skiing technique.

The prehistoric skis from Lendbreen, Digervarden and Dalfonn have not been published earlier, and will receive most attention in this paper. The two skis from 
Vossaskavlen will be summarized to clarify their age and context. In addition, three other ski finds of more recent or uncertain date will be given a short description.

\section{Ski history and typology}

Before delving into the details of the individual ski finds, it is probably helpful to provide some ski-historical context. The earliest find claimed to be a ski is from Siberia and dated to C. 6000 BCE (Burov 1989). The earliest ski finds in the Nordic countries are the skis from Kalvträsk, Sweden (c. 3200 BCE, Åström and Norberg 1984, 84) and Drevja, Norway (c. 3100 BCE, Sørensen 1993a, 107). These oldest ski finds have remained isolated finds from their time with few points of interaction with other assemblages. Therefore, they have been treated more as curiosities than focal points of research. A remarkable number of prehistoric and medieval skis are known from Sweden and Finland (c. 90 in each country), with Norway has fewer with 23 skis (Manker 1971, 78; Berg 1993, 75; Sørensen 1993a). Even though finds have been fewer, skiing has been a key part of national history in Norway. During the late nineteenth century and early twentieth century Norway was seeking its place as an independent nation and skiing became vital in the process. The famed polar explorer Fridtjof Nansen cemented the belief that Norwegians were a particularly skiworthy people (Leich 2009, 6). In his book about the Greenland crossing he devoted an entire chapter to the history and development of skis (Nansen 1890). Seen in this context all ski finds have been treated as important for the understanding of Norwegian heritage.

The current typology of skis separates them into types based mainly on their type of foothold (Manker 1971). The typological work by Ernst Manker furthered earlier work laid down by Gösta Berg (1950). In lieu of funds to conduct a radiocarbon-campaign, it was deemed productive to make a complete inventory of skis and create a typology to better understand the breadth of the material (Figure 2). In Manker's work type A has a flat foothold with vertical holes for the binding, and a flat underside without longitudinal grooves. Type B has a slightly raised foothold with raised wood along the side of the foot, in which there are horizontal holes for the binding. The underside is flat and without grooves. Type $C$ has a raised platform for the foot, with a horizontal hole for the binding through the foothold. Type $C$ has four subtypes based on the character of the underside, of which type C1, with a flat or slightly convex underside without grooves, is the most common type and of special interest here. Types A and B are very rare. The only representative of type A known from the Nordic countries is the Kalvträsk ski.

Fur-lining of the underside is known from more recent Nordic skis (Sørensen 1993a; Vilkuna 1998), with the c. 500 CE ski from Mänttä being the earliest known example until now. Furs may have been attached using sinew through holes along the edges of the ski, with iron or wooden nails, sown across the upper side of the ski or glued to the underside (Sørensen 1993a, 96). The two last techniques would not leave traces showing the original presence of fur. Such a presence would have to be indicated by other means such as a rough underside not suitable for gliding on or an underside without traces of wear. Only the presence of longitudinal grooves makes fur-lining unlikely. 


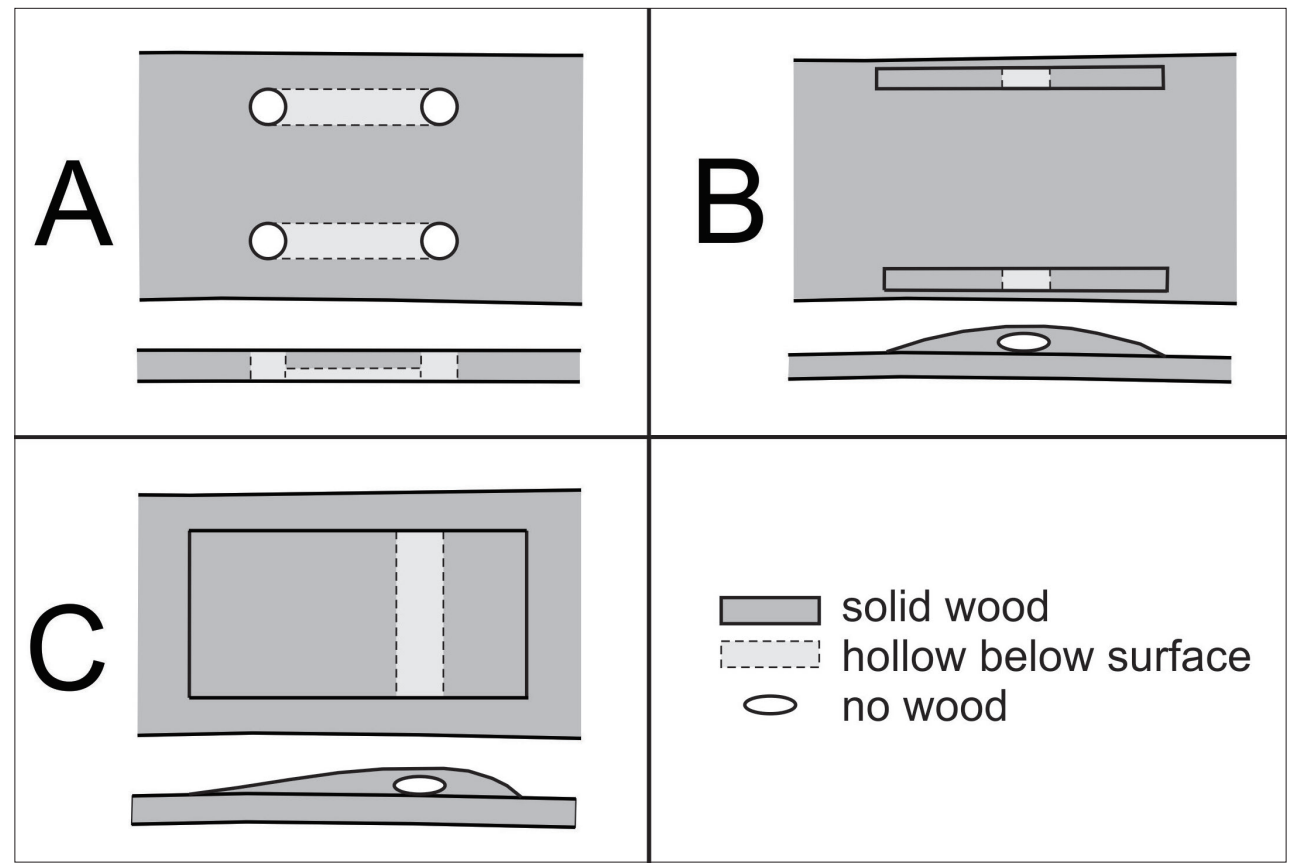

Figure 2 Manker's ski typology, based on the foothold. Skiing direction is towards right. Drawing: Lars Pilø, Oppland County Council.

The skis from glacial ice will be presented in the following, including a brief description of the main sites. We start with a unique and enigmatic Bronze Age find from the Lendbreen ice patch.

\section{The Lendbreen find-ski or snowshoe?}

Lendbreen is a very large ice patch, situated on the north side of the mountain ridge Lomseggen at a height between 1690 and 1920 m.a.s.l. It is by far the most complex ice site investigated in Oppland County. The site was first visited by archaeologists in 2006, but the first systematic surveys took place in 2011 and are still on-going. It combines the usual reindeer hunting remains (dated from C. $1300 \mathrm{BCE}$ to $1500 \mathrm{CE}$ ) with a mountain route crossing the ice (with finds dating from c. 300 to $1700 \mathrm{CE}$ ). Most finds are concentrated in the pass area at the top, with scattered finds further down the slope, many of which were probably moved downhill by meltwater.

Four fragments of a short ski or snowshoe have been recovered at Lendbreen during archaeological fieldwork 2011-2013 (Figure 3). The ambiguity associated with this being a ski or a snowshoe will be addressed below. The first and largest fragment was found at the top of the ice patch in 2011. Subsequently three additional fragments were found further down the slope in 2012-2013, in the direction of fall from the first find. The distance between the recovered fragments of the ski/snowshoe is up to 300 $\mathrm{m}$. The ski/snowshoe is radiocarbon-dated to cal BCE 791-540 (Table 1).

1. All radiocarbon dates are given with two sigmas, unless otherwise stated. Dates are calibrated using Oxcal Intel 13, when possible. 
Prehistoric and Medieval Skis from Glaciers and Ice Patches in Norway

Table 1 Radiocarbon dates for ski mentioned in the paper.

\begin{tabular}{lllll}
\hline Ski & Museum\# & Wood species & Age & Lab\# \\
\hline Lendbreen & C57874/22 & Pine & $2510 \pm 30$ BP, cal BCE 791-540 & Beta-343077 \\
Digervarden & C59805/1 & Birch & $1270 \pm 30$ BP, cal CE 663-859 & Beta-390772 \\
Dalfonn1 & C36673 & Pine & 500 CE & Unknown \\
Dalfonn2 & C55715 & Pine & $1448 \pm 27$ BP, cal 566-651 CE & UBA-29708 \\
Vossaskavelen & SK201a-6 & Pine & $1215-1290$ CE & Unknown \\
Langfonne & C59804/1 & Pine & $124 \pm 23$ BP, cal 1680-1939 BCE & UBA-29728
\end{tabular}

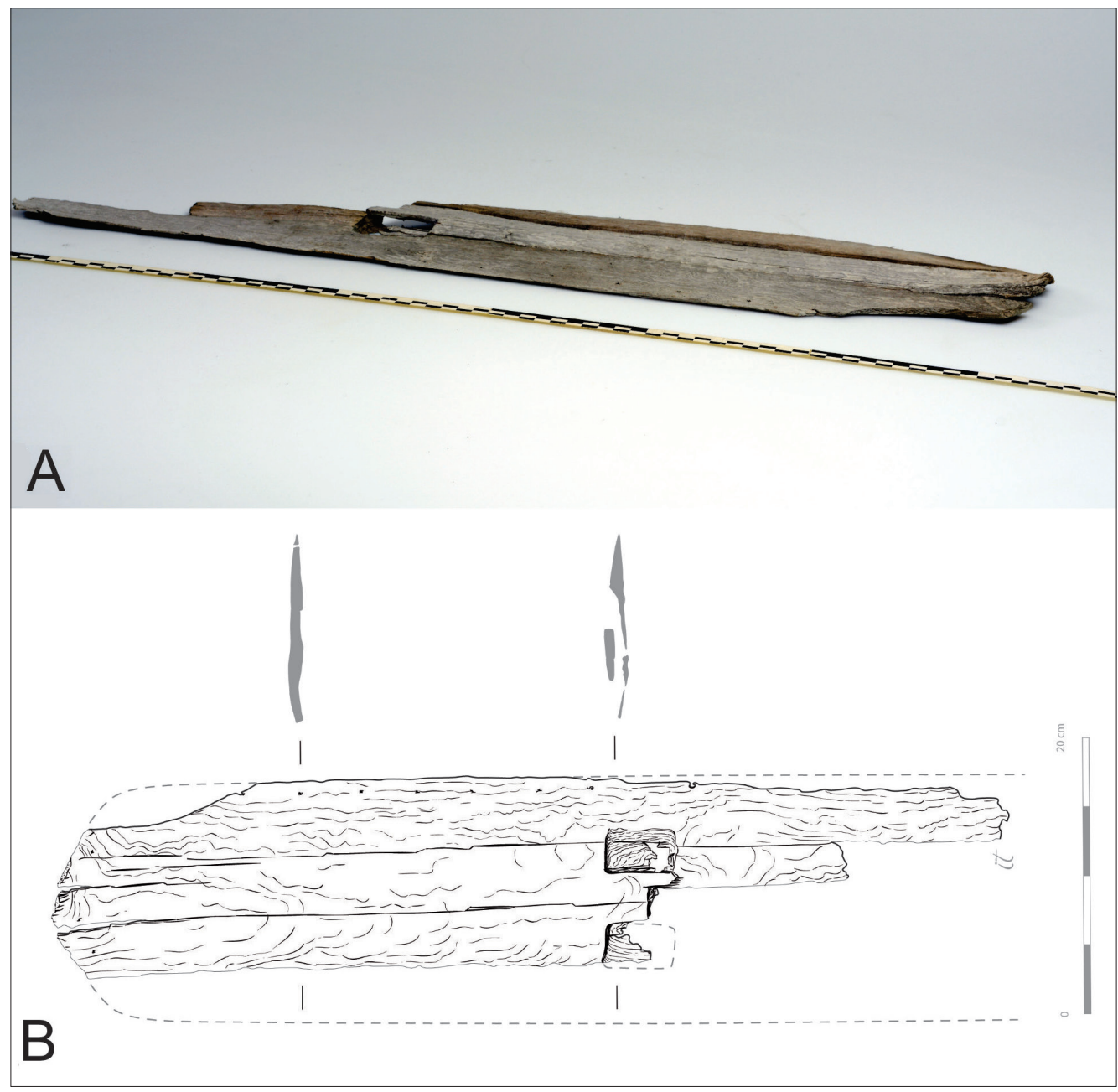

Figure 3 A: The Lendbreen ski/snowshoe. Photo: Vegard Vike, Museum of Cultural History, University of Oslo. B: The Lendbreen ski/snowshoe or snowshoe with a reconstructed outline. Drawing: Ingvild Tinglum Bøckman.

(C) Equinox Publishing Ltd. 2018

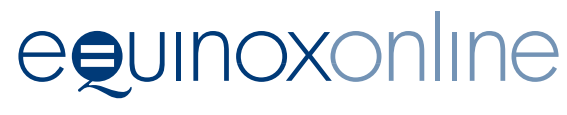


The ski/snowshoe (C57874/22) is made of pine. One long side and one end have not been found yet. These parts may be lost or they may still be inside the ice. Since the center and other long side are preserved, it is possible to estimate the original width based on symmetry. The length is more difficult to estimate; even more so since it is not clear if the preserved end is the front or the back of the ski/snowshoe. After being fitted together, the preserved fragments measure $68 \mathrm{~cm}$ in length and $13 \mathrm{~cm}$ in width. Based on symmetry the original width of the ski was approximately $18 \mathrm{~cm}$ at the binding and $20 \mathrm{~cm}$ at the preserved end. The thickness is greatest in the center$1.5 \mathrm{~cm}$, while the thickness at the edges is only $0.5 \mathrm{~cm}$. It should, however, be noted that the wood probably has thinned somewhat due to surface erosion and shrinkage.

The binding area of the ski/snowshoe is preserved, but is broken into four parts of which one part is missing. The binding area contains two rectangular depressions which are $5.3 \times 3.2 \mathrm{~cm}$ (1 cm deep), separated by $3.4 \mathrm{~cm}$ of wood. Through the wood between the two rectangular depressions there is a narrow passage measuring $3.4 \mathrm{~cm}$ in width and $0.6 \mathrm{~cm}$ in height. The binding must have passed through here, and since the passage is very narrow, the material for the binding was most likely leather or rawhide, not withe. The holes for the binding are placed $4.5 \mathrm{~cm}$ from the outer edge of the ski (based on the preserved side). The shape of the binding area is without parallels in the published Nordic ski material.

The length from the end of the ski/snowshoe to the center of the binding is $42 \mathrm{~cm}$. If the binding was placed symmetrically in the center this would result in a length of $84 \mathrm{~cm}$. However, it is possible that the back part was longer than the front part. Otherwise, too much pressure on the back part would make it dig into the snow, making the ski/snowshoe less functional. Since we do not know if it is the front or the back of the ski/snowshoe that is preserved, the exact length of the original is difficult to determine. It appears likely that the preserved end is the front. If the preserved end was the back, this would result in a very short ski/snowshoe, which broadens at the end, which appears less likely.

There are small holes with a distance of $4 \mathrm{~cm}$ along the edges of the ski/snowshoe. The holes derive from the fastening of fur-lining with sinew. There are no wear traces on the underside of the ski, just as would be the case if the underside had been protected by fur. This is the earliest known certain use of fur-lining in the published ski material from the Nordic countries, more than a thousand years older than the Mänttä ski (Vilkuna 1998).

More complicated is the absence of a clear tip at the preserved end of the ski, especially since this is likely the front. Two of the preserved pieces have no clear indication of a tip. The third piece has a slight curve at both ends of the fragment, so this is likely caused by post-depositional deformation. Without a tip the find from Lendbreen could not have been used as a normal ski for gliding on the snow. If it is some kind of snowshoe, it is without parallels. Either way, the ski/snowshoe from Lendbreen is unique in the published prehistoric and medieval material. However, it has some parallels in eighteenth through nineteenth century short and broad skis with a Manker type A binding from Eastern Siberia, as can be seen in the exhibitions at the Russian Ethnographic Museum in St. Petersburg and at the Ski Museum in Oslo. 


\section{The Digervarden ski}

The large ice patch to the east of Mount Digervarden $(1780 \mathrm{~m})$ was surveyed for the first time in 2014, and again in 2016. In addition to the ski described below, four arrows, six Iron Age scaring sticks, a piece of undated fabric and an eighteenth century sled have been recovered. Two of the arrows have nearly identical calibrated radiocarbon dates (cal 756-414/413 $\mathrm{BCE}$ ), while one arrow can be dated to the seventh and eighth century $\mathrm{CE}$, based on the shape of the iron arrow point.

The Digervarden ski (C59805/1, Figures 4-7) was found at the lower edge of the central part of the ice patch in 2014. It is radiocarbon dated to cal CE 663-859. It is of a known type, belonging to Ernst Manker's type C1 (Manker 1971): Ski with a raised footrest narrower than the actual ski, and with a horizontal binding hole passing under the foot. There are no grooves on the underside.

The ski is complete, but a few small pieces have broken off the right side of the front part. The front of the ski is bent downwards due to post-depositional snow pressure (Figure 4). The ski is made of birch, is $170 \mathrm{~cm}$ long and the width is $14.7 \mathrm{~cm}$. The thickness is greatest in the binding area $(2.9 \mathrm{~cm})$. The thickness is otherwise around $1 \mathrm{~cm}$, which is probably somewhat less than the original thickness due to erosion and shrinkage.

There is a small round hole in the tip of the ski. This feature is also known from other prehistoric and medieval skis and from traditional skis today. One explanation for this hole is that it is a remnant from the bending of the ski tip. It is also known

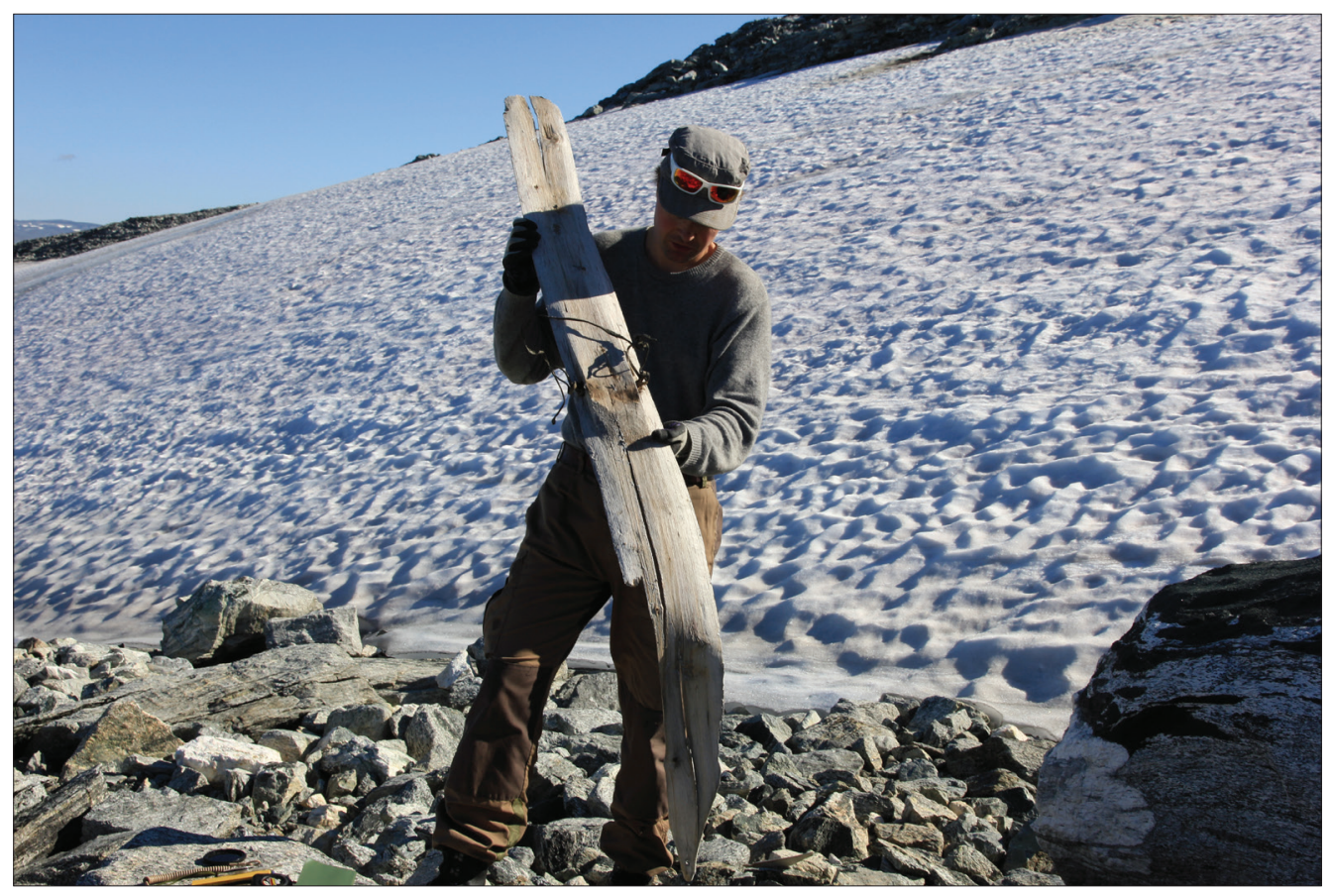

Figure 4 Runar Hole holding the Digervarden ski at the find spot. Photo: Aud Hole/ Oppland County Council. 


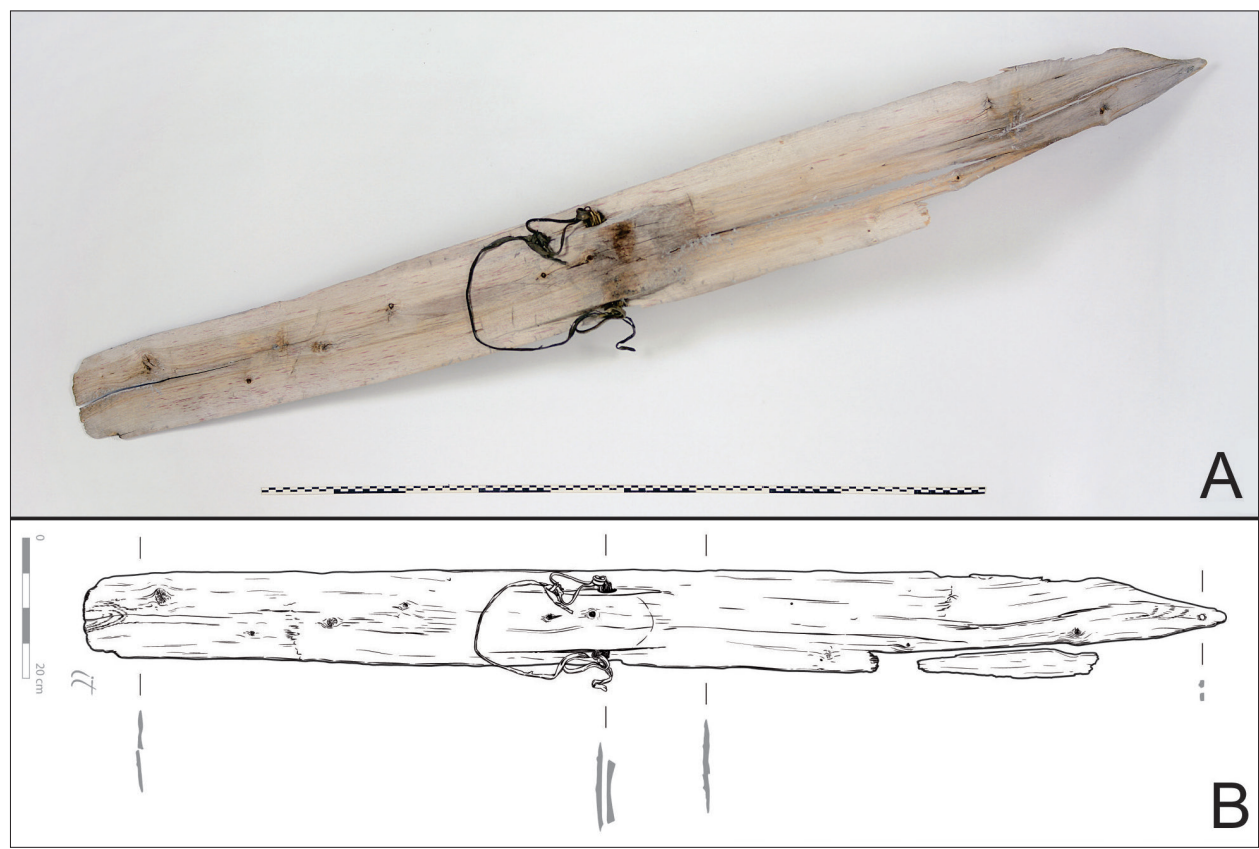

Figure 5 A: Photo of the Digervarden ski. Photo: Vegard Vike, Museum of Cultural History, University of Oslo. B: Drawing of the Digervarden ski. Drawing: Ingvild Tinglum Bøckman.

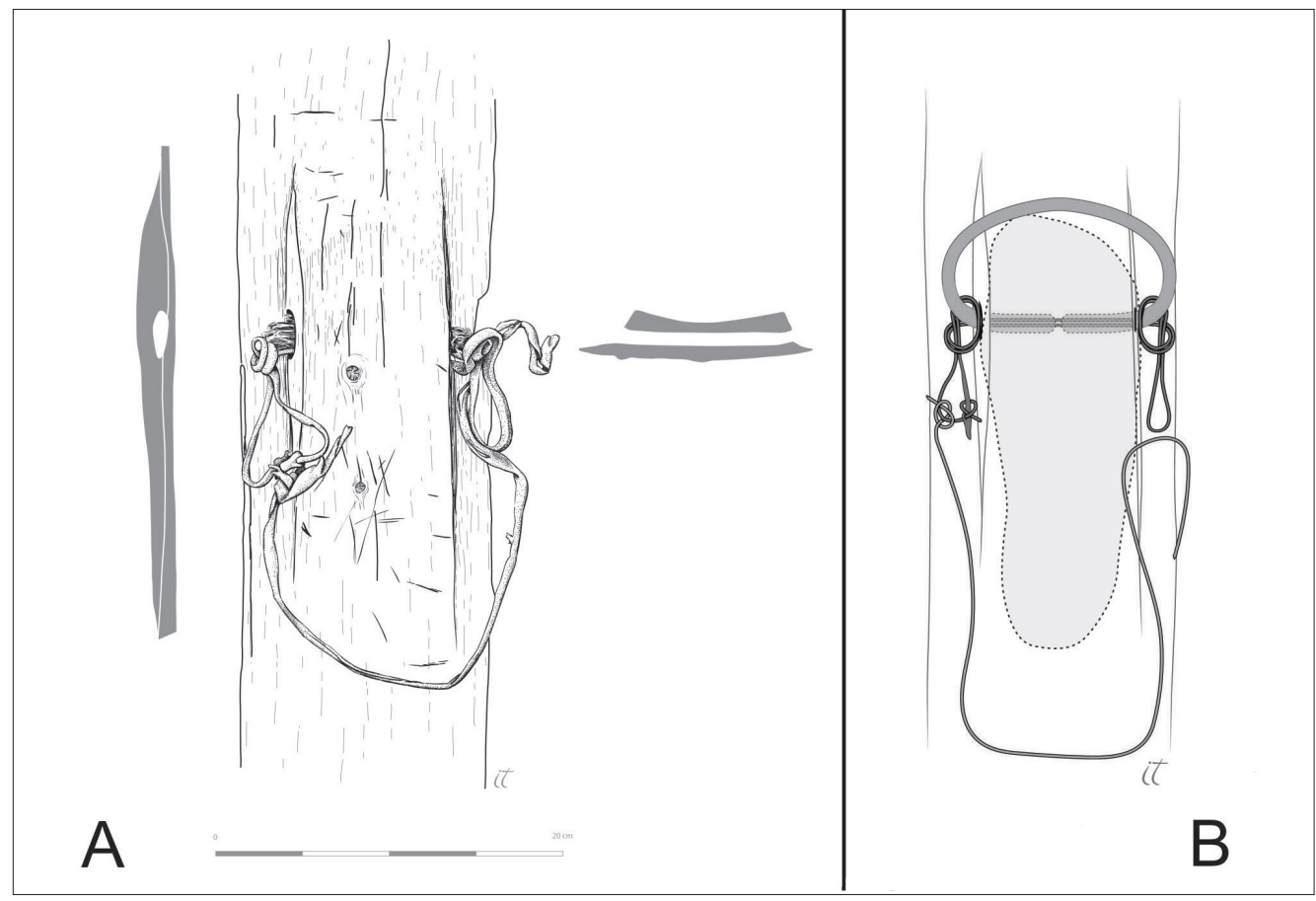

Figure 6 A: Detail of the binding of the Digervarden ski. B: Detail of the reconstructed binding. Drawing: Ingvild Tinglum Bøckman. 


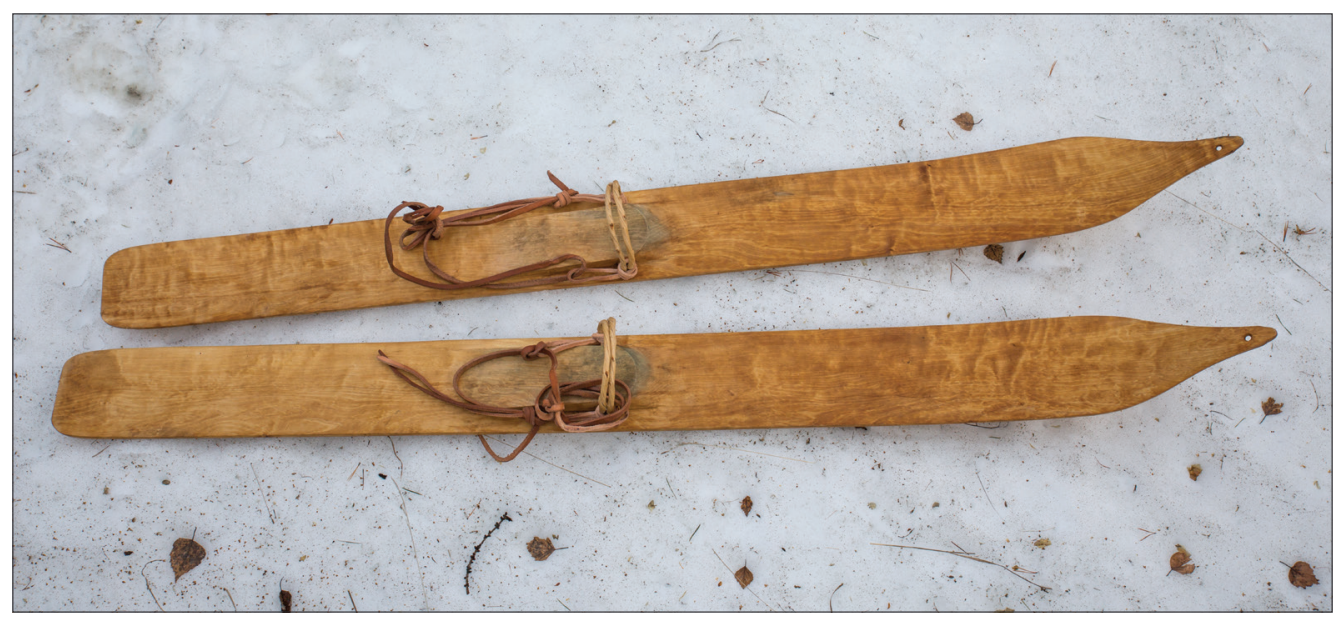

Figure 7 Reconstructed pair of Digervarden skis. Reconstruction by Kjell Bengtsen. Photo: Espen Finstad, Oppland County Council.

from more recent times that rope or string was attached to the hole to allow for dragging the skis when the skier was walking on foot. A third known function is that strings were attached to the ski tip to facilitate steering when going downhill (Berg 1993, 55, Wiklund 1931, 22ff). There are no grooves, raised edges or clear wear traces on the underside of the ski. This opens the possibility that the ski may have been lined with fur, even if there are no holes for sinew.

The preserved binding enhances the importance of the Digervarden ski. Preserved bindings on prehistoric skis are very rare, and the only published example beside the Digervarden ski is the 1500-year-old Mänttä ski, published by Janne Vilkuna (1998). This is also a Manker type C1 ski, and with holes for attaching fur along the sides. In the horizontal hole passing under the foot of the Digervarden ski there are remains of withe used in the binding around the front of the foot. A double leather string goes through the same hole. On both sides, this string forms a loop (Figures 5B and 6B). A long leather string is fastened to the left loop. Most likely, this long string is part of a heel binding.

Types of binding have been much discussed in publications on ski history (Berg 1993). The oldest drawings documenting Norwegian ski bindings are from the seventeenth century. They depict a toe binding of withe and a heel binding of leather. Sami skis from the last two-three hundred years also have both toe- and heel-binding, but show many different types of binding techniques (Berg 1993). Both the Mänttä ski and the Digervarden ski show that the use of a heel binding has a long tradition. Skis with a heel-binding make it possible to add power to the step forward and provide a much better stability than skis with just a toe-binding. This is a great help when going uphill. With a heel binding it is also much easier to steer during skiing downhill or on flats. Skis with only a toe binding are more suitable when the ski is used intermittently-skiing some distances and walking others.

In contrast to the Lendbreen ski/snowshoe, the Digervarden ski fits well into the known regional and Nordic ski material. The ski from Alvdal, Hedmark County 


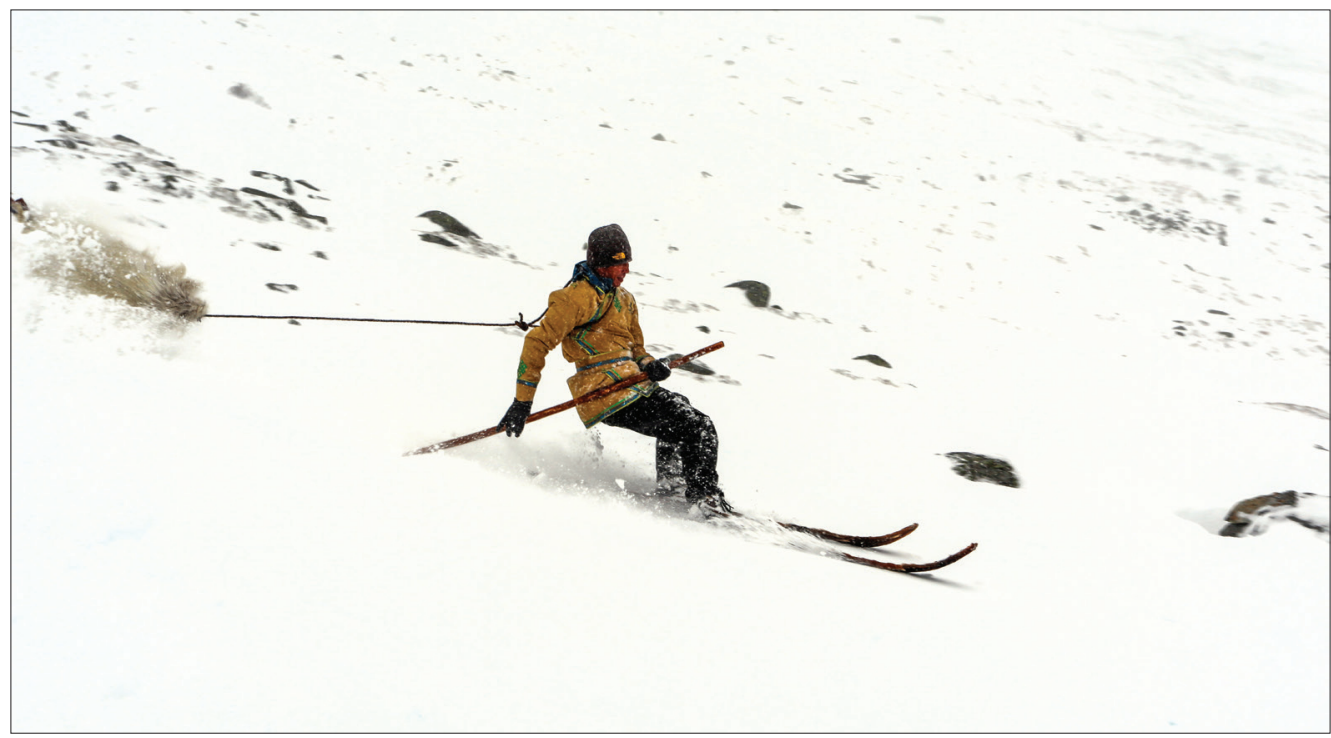

Figure 8 Ma Liqin, traditional skier from Chinese Altai, showing the technique of using a single pole as a rudder during downhill skiing. Photo: Espen Finstad, Oppland County Council.

(Sørensen 1993b) is very similar and with a slightly older date, but has two grooves underneath. This ski has the same width, but is c. $30 \mathrm{~cm}$ shorter than the Digervarden ski. The incomplete Utrovatn ski, also from Oppland County, has a raised foothold and a width of $13 \mathrm{~cm}$, with a groove underneath (Sørensen 1995a). This ski is radiocarbon-dated to the Viking Age, i.e. slightly younger than the Digervarden ski (Sørensen 1995b, 48).

Experiments with a reconstructed pair of Digervarden skis show that they are fully functional. Since the foot is not stuck in a firm binding like modern skis, it is not possible to change course by adding more weight to the outer ski in the bend as it is done today. Traditional skiers from the Chinese Altai Mountains use similar skis combined with a single pole. During skiing, they lean backwards and use the pole as a steering pole (Figure 8). A traditional skier from Altai, Ma Liqin, tried out the reconstructed Digervarden skis during a visit to Oppland in 2015. He said they worked well, but he was convinced that they must have been fur-lined as all traditional skis in Altai are. Otherwise, one gains too much speed downhill, which can be hazardous, or will have too little traction going uphill.

\section{The Søre Dalfonn skis}

Søre Dalfonn is a small ice patch extending from a canyon. The lower edge is at c. 1500 m.a.s.l. The ice patch has released two skis (Hole 2015). The first one was found by Helge Hole in 1980 (Dalfonn 1). Hole also found a second ski here in 2002 (Dalfonn 2). The ice patch has also yielded Iron Age arrows.

The Dalfonn 1 ski (C36673a, Figure 9) was radiocarbon-dated to c. AD 500 shortly after it was found, according to the catalogue at the Museum of Cultural History, 


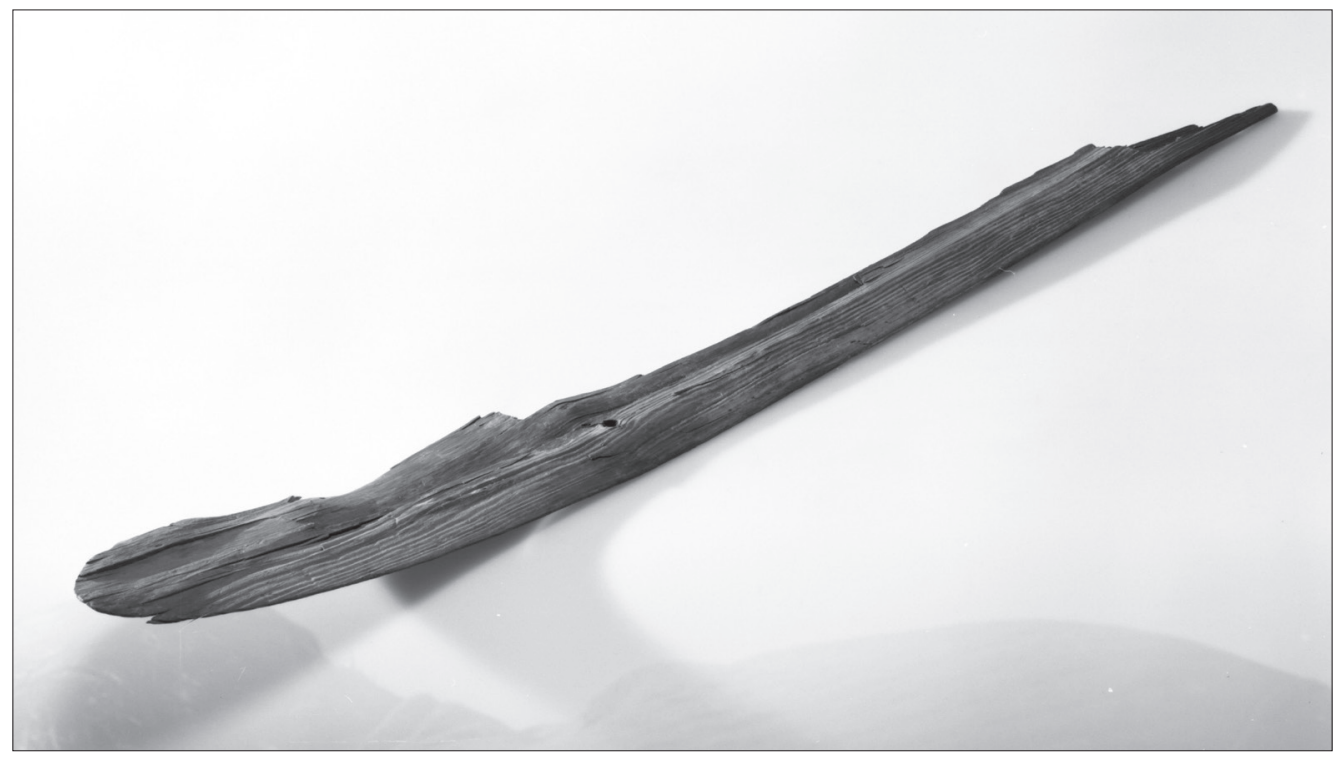

Figure 9 The Dalfonn 1 ski. Photo: Museum of Cultural History, University of Oslo.

University of Oslo. Unfortunately, it has proven impossible to locate the original radiocarbon report. The front part of the ski is preserved to a length of $88.5 \mathrm{~cm}$, with a greatest width of $9.5 \mathrm{~cm}$. The thickness varies, but it is only $1 \mathrm{~cm}$ at most. Along the top of the front half there is a raised ridgeline. There are no remains of the binding area and no information is available on wood species.

The Dalfonn 2 ski (C55715) is dated to cal. 566-651 CE. The ski is delaminated and is preserved in 13 larger pieces up to $\sim 50 \mathrm{~cm}$ and numerous fragments. On one fragment there is preserved a raised ridge that would have run along the center of the skis upper side, just as on the Dalfonn 1 ski. No clear binding area is visible on the fragments. It is made from pine.

The two Dalfonn skis could possibly be a pair. The dates are similar, they share the same raised ridgeline and the finder believes they were found in nearly the same spot (Hole 2015, 9).

\section{The Vossaskavlen ski pair}

Two skis (Figure 10) were found at the northern part of Vossaskavlen ice patch in Hordaland County in $1931^{2}$ and 1963, respectively (SK201a-6). The ice patch has also yielded remains of a sled from c. 600 CE (Bjørgo et al. 2015). The general area is known as an important mountain crossing in historical times (Tobiassen 1988).

The skis are so similar that it is very likely that they are a pair. A radiocarbon date from the ski found in 1963 gave cal 1215-1290 CE (Sørensen 1995b, 63). This was quite surprising to ski historians, who are more inclined to date the skis to no earlier than

2. Different years are given in the literature for when this find was made. We use the year given in Sørensen 1995b, 63 as this is the most detailed source.

3. Source does not give BP-date. Calibration method given as "Stuiver". 


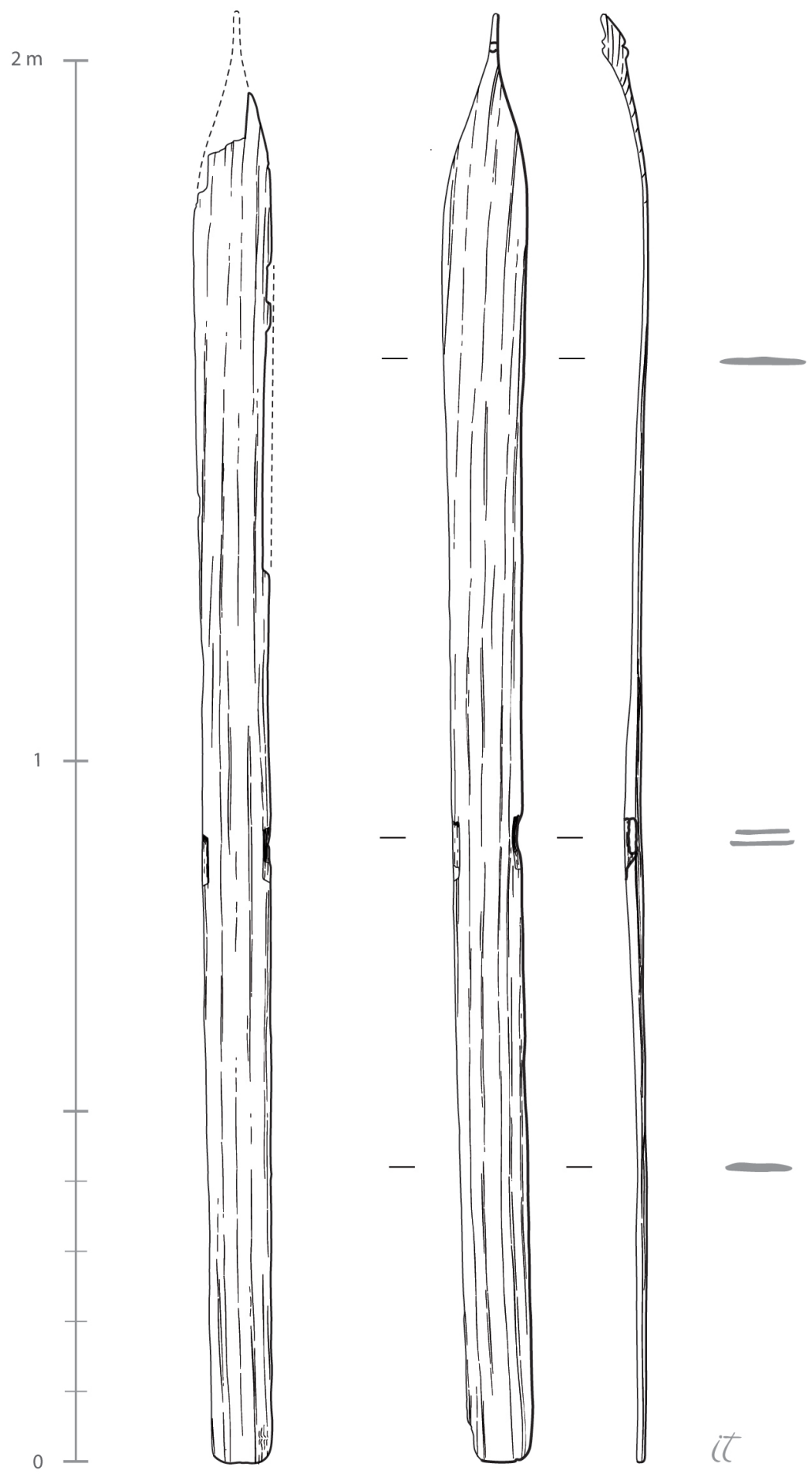

Figure 10 The Vossaskavlen ski pair. Drawing: Ingvild Tinglum Bøckman.

(c) Equinox Publishing Ltd. 2018

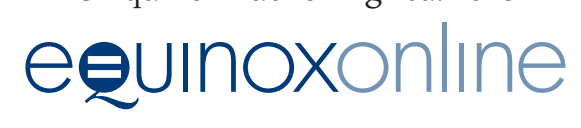


$1600 \mathrm{CE}$, based on the craftsmanship and the shape of the carved ski tip. The skis are made of pine, and even with a potential old wood problem, it appears unlikely that the wood is 400 years older than the ski. Traditionally, skis are not made from large, old pines (Thomas Aslaksby, pers. comm.). Theoretically, they could be made from bog wood or reused wood, but this appears unlikely. Steinar Sørensen (1995b, 63) did claim that the ski could only have been preserved by expanding ice if it had been lost during the Little Ice Age since it otherwise would have deteriorated. In view of more recent glacial archaeological observations this claim is too simplistic. We now know that the context around ice patches is much more dynamic when it comes to snow melting cycles. The numerous other finds from the same time recovered in Oppland attest to this (Pilø et al. 2018) Wooden objects can preserve for some time outside the ice at high altitude. The variation in ice patch sizes also depends on factors other than temperature (Ødegård et al. 2017).

The binding area of the ski differs from the prehistoric skis, but fits well into what is known from Nordic skis from the Medieval and Post-Medieval Period (Sørensen 1996). The same goes for the narrow width $-10 \mathrm{~cm}$ at the binding.

\section{Other ski finds}

A ski tip was recovered from the Langfonne ice patch in 2014. It is a flat piece of pine with profiled sides. The ski tip has been twisted 90 degrees to the plane of the ski. The profiled edges are reminiscent of an acanthus-ornamentation, which was popular from the Medieval Period and onwards. It is radiocarbon-dated to cal 1680-1939. There is a more than $80 \%$ probability that the ski tip is from the late seventeenth, eighteenth or nineteenth century.

A 1953 correspondence between Sigurd Grieg, director of the Maihaugen museum in Lillehammer, and Professor Bjørn Hougen, Universitetets Oldsaksamling in Oslo, reveals the find of a ski from glacial ice from Mount Storhø in Lesja, Oppland County. It was reportedly found in the snow in a place where there used to be a glacier. The letter from Grieg states that the ski was bent the wrong way (similar to the Digervarden ski) and that it had a groove on the underside. The Maihaugen museum was allowed to keep the ski, but it has unfortunately not been possible to locate it in the museum storage.

Recently, the front part of a wooden ski was reported from the Hardangerjøkulen Glacier (Pilø 2017). The find was made in 1987, but only reported in 2016. The ski is not radiocarbon-dated yet, but is believed to be no more than two or three centuries old at the most, based on the narrow width of the ski and the active glacier context.

\section{Discussion}

The context of the skis from the glacial ice is very different than other old skis preserved in bogs in the Nordic countries and North-West Russia. It appears, however, that the glacial skis are essentially not typologically different from the bog skis, even though the high-alpine landscape and snow conditions where they were used would have been very different from the lowlands. The exception is the Lendbreen ski or snowshoe, which has no parallels among the lowland finds. 
Even though recreational skiing now dominates the use of skis, they were traditionally used for transport and hunting only. Skis are still used in this way in some areas in Asia, such as in the Altai Mountains. Very likely hunting and transport in a high-alpine landscape were the main uses for the skis from the glacial ice as well. All ice patches with archaeological finds in Oppland have artefacts associated with hunting, including Digervarden, Lendbreen and Dalfonn. It may well be that the recovered skis belonged to hunters. Medieval sources such as the "Kings Mirror" and the "Landslov" (unified code of law for Norway) of King Magnus Lagabøte, both thirteenth century, tell us that hunting on skis was practiced. The animals were an easy target for the ski hunters in deep snow. The hunters could track the animals in the snow and they could also ski down from above, using the speed gained in the slope to close in for the kill.

Hunting of reindeer on the ice patches was normally a summer activity. It appears unlikely that skis were much used during summer hunts, at least in the Iron Age when summer-hunting was often undertaken by larger groups of hunters in a communal hunt, controlling the movement of the reindeer herd as they gathered on the ice to avoid pestering insects (Pilø and Finstad in press). From recovered buck antlers, naturally shed during early winter, we know that reindeer were also present on the ice patches in the winter. So, winter hunting on the ice patches was possible.

There is a natural all-year migration route for the reindeer over the Digervarden Mountain. The topography of the terrain canalizes the moving herds in the area where the ski was found. Five hunting blinds are situated on the ridge here, showing that hunters were aware of this, and used the topography during summer hunts. The area of the ski find would also have been a good hunting ground in the winter, when the reindeer sought higher wind-blown ground to seek food. Perhaps the ski was lost during the hectic hunt or in a small avalanche. There is, however, an old mountain route just east of Digervarden, and it may be that the ski found here is related to transport, rather than hunting, if it makes sense to draw such a division.

The Vossaskavlen skis are from a site where a sled has also been found, albeit much older than the skis (Bjørgo et al. 2015, 78). It is not clear whether the skis are related to hunting or transport. No artefacts associated with hunting have been recovered at this site so far.

The Lendbreen ski/snowshoe is the odd one out in this context. If it had been found in a bog in the lowlands, it would have been tempting to describe it as a ski/snowshoe for short distance movement around the camp. The high-alpine context of the find indicates a very different use. The shortness, the width and the fur-lining are all indications of a use in deep snow. It was found in a pass area, but the earliest transport-related finds here so far are from c. $300 \mathrm{CE}$, i.e. significantly later than the ski. However, this does not exclude that the ski was used during a winter-crossing of the mountain ridge in the Late Bronze Age.

\section{Conclusion}

The melting of glacial ice in the high mountains has provided important new ski-historical evidence. These are skis that were lost during hunting or transport in a 
high-alpine landscape, i.e. during their actual use. They were likely used during the wintertime and thus provide evidence of early human use of a high-alpine landscape under what could be harsh conditions.

While the skis from Digervarden, Dalfonn and Vossaskavlen fit quite well into our current knowledge of ski development, the Lendbreen ski or snowshoe provides a glimpse of an unknown tradition of making implements for deep snow transport. The on-going melting of high mountain ice is likely to release further ski-historical evidence in the coming years.

\section{Acknowledgements}

We would like to thank the Ministry of Climate and Environment, The Directorate of Cultural Heritage, Oppland County Council and the Museum of Cultural History, University of Oslo for funding the Glacier Archaeology Program in Oppland. We would also like to thank ski-maker Thomas Aslaksby for fruitful discussions on the Vossaskavlen skis, Kjell Bengtsen for the reconstruction of the Digervarden ski and Dag Inge Bakke for trying out the Digervarden reconstructions. Thanks to James Barrett for valuable comments on an earlier draft of this paper. The manuscript benefited from comments from two anonymous reviewers.

\section{References}

Andrew T. D. and G. MacKay. 2014. "The archaeology and paleoecology of alpine ice patches: A global perspective." Arctic 57(3): iii-vi.

Åström, K. and O. Norberg. 1984. "Förhistoriska och medeltida skidor." Västerbotten 2, 82-88. Umeå: Västerbotten museum.

Berg, G. 1950. "The origin and development of the skis through the ages." In Finds of Skis from Prehistoric Time in Swedish Bogs and Marshes, edited by Magnus Lundqvist and Marshall Lagerquist, 9-64. Stockholm: Generalstabens litografiska antalts förlag.

Berg, Karin. 1993. Ski i Norge. Oslo: Aventura.

Bjørgo, T., T. Linge, $\varnothing$. Skår, S. Rongved and T. Slinning. 2015. "Fragments of a Late Iron Age sledge melted out of the Vossaskavlen snowdrift glacier in western Norway." Journal of Glacial Archaeology 2: 73-81. https://doi.org/10.1558/jga.v2i1.27719

Burov, G. 1989. "Some Mesolithic wooden artifacts from the site of Vis I in the European north east of the U.S.S.R." In The Mesolithic in Europe: Papers Presented at the Third International Symposium Edinburgh 1985, edited by Clive Bonsall, 391-401. Edinburgh: John Donald Publishers.

Dixon, E. J., M. Callanan, A. Hafner and P. G. Hare. 2014. "The emergence of glacial archaeology." Journal of Glacial Archaeology 1(1): 1-9. https://doi.org/10.1558/jga.v1i1.1

Hole, R. 2015. Rapport. Arkeologiske funn av tre-restar etter ei ski 1980 og 2002. Søre Dalfonn nedanfor Kjølen. Lesja kommune. Oppland Fylke. Reinheimen Nasjonalpark. Tarandus.

Leich, J. 2009. "Nordic skiing from Stone Age to skating." Journal of the New England Ski Museum. 75.

Manker, E. 1971. "Fennoskandias fornskidor: Preliminär rapport från en inventering." Fornvännen 66: 77-91.

Nansen, F. 1890. Paa ski over Grønland: en skildring af Den norske Grønlands-ekspedition 1888-89. Kristiania: Aschehoug. 
Ødegård, R. A., A. Nesje, K. Isaksen, L. M. Andreassen, T. Eiken, M. Schwikowski and C. Uglietti. 2017. "Climate change threatens archaeologically significant ice patches: Insights into their age, internal structure, mass balance and climate sensitivity." The Cryosphere 11: 17-32. https://doi.org/10.5194/tc-11-17-2017

Pilø, L. 2017. "An old ski from the Hardangerjøkulen Glacier.” http://secretsoftheice.com/ funn/2017/02/15/old-ski-hardangerjokulen/

Pilø, L., E. Finstad, C. Bronk Ramsey, J.R.P. Martinsen, A. Nesje, B. Solli, W. Wangen, M. Callanan and J. H. Barrett. 2018. "The chronology of reindeer hunting on Norway's highest ice patches." Royal Society Open Science 5: 171738. http://dx.doi.org/10.1098/rsos.171738

Pilø, L. and E. Finstad. in press. "Ancient reindeer hunting in Oppland, Norway." In The Gazelle's Dream: Game Drives of the Old and New Worlds, edited by A. Betts and W. P. van der Pelt. Sydney: Sydney University Press.

Reckin, R. 2013. "Ice patch archaeology in global perspective: Archaeological discoveries from alpine ice patches worldwide and their relationship with paleoclimates." Journal of World Prehistory 26(4): 323-385. https://doi.org/10.1007/s10963-013-9068-3

Sørensen, S. 1993a. "Skifunnet fra Steinhaugmo og de skinnkledde skiene i Fennoskandinavisk fortid." Viking tidsskrift for norrøn arkeologi 56: 87-111. - 1993b. "Skifunnet fra Alvdal." Årbok for Nord-Østerdalen 1993: 26-36.

. 1995a. "Skifunnet fra Utrovatn og den eldste skitradisjonen i Valdres." Årbok for Valdres 1995: 155-166.

. 1995b. "Skihistorie i tusen år. Fortalt gjennom syv funn i Skimuseet." Skiforeningens årbok 1995: 46-64

- 1996. "Daterte skifunn fra middelalderen. Et omriss av middelalderens skihistorie." Collegium Medievale 9: 8-55.

Tobiassen, A. H. 1988. Driftehandel med storfe i Norge, ca. 1850-1920. Unpublished PhD thesis, Institute of Ethnology, University of Oslo.

Vilkuna, Janne. 1998. "The binding of the prehistoric ski from Mänttä, Finland.” History of Skiing Conference, Oslo in 1998: 70-74.

Wiklund, K. B. 1931. “Den nordiska skidan, den södra och den arktiska.” På skidor 1931: 5-50. 